How to Cite

Azma, F., Farahbakhsh, M. T., Safarzad, R., \& Farahnaki, E. (2019). Investigating relationship of talent management and organizational entrepreneurship. International Journal of Life Sciences \& Earth Sciences, 2(1), 25-37.

https://doi.org/10.31295/ijle.v2n1.76

\title{
Investigating Relationship of Talent Management and Organizational Entrepreneurship
}

\author{
Fereydoon Azma \\ Islamic Azad University \\ Mohammad T. Farahbakhsh \\ Islamic Azad University \\ Reza Safarzad \\ Islamic Azad University \\ Email:r.safarzad@gmail.com
}

Ehsan Farahnaki

Islamic Azad University

\begin{abstract}
Introduction: talent management is a comprehensive strategy and an approach to international human resource practices and a commitment to widespread sharing of the belief that human resource is a priority and a source of competitive advantage. Talent management ensures the organizations that competent individuals with the right skills have taken the right position. The aim of this study was to investigate the relationship between talent management and organizational entrepreneurship. Methodology: The present study is an applied one in terms of its nature and purpose, and it is a descriptive and correlational one in terms of the data collection method to test the hypothesis. The population of this study included experts, officials, supervisors and middle and top managers of Golestan province Gas Company who have at least 7 years' experience. Accordingly, a total number of 51 participated in the study. A questionnaire was used to collect data. Data analysis was carried out through SPSS software for descriptive data and SMART PLS software for inferential data. Results: This study shows that there is a significant positive relationship between talent management and organizational entrepreneurship, and components of each of the main criteria also have a significant relationship with each other. Conclusion: The findings suggest that managers should improve their organization's talent management system in order to increase innovation and competitiveness. These systems can complete and implement various initiatives by creating opportunities to achieve talent resources and providing transparency in selection criteria.
\end{abstract}

Keywords---entrepreneurship, organizational entrepreneurship, talent management process, talent management.

\section{Introduction}

Organizations are struggling to balance the needs for talent in different generations in the workplace (Du Plessis et al., 2010). Talent management is a complex procedure for organizations, but organizations need talented employees to maximize their organizational performance. Talent management, when continuing in a positive manner, improves productivity and increase competitiveness while reducing the waste of time (Yalcin Vural et al., 2012).

The current economic status of the world has increased the importance of talent management and its retention. The importance of talent management is considered as the secret to success in many companies around the world, and talented staffs are the main source of success in any enterprise (Hussain Al-Fadhli, 2014). Since today business should be integrated globally, talent is considered as a powerful source of competitive advantage. However, many

ISSN 2632-9425

Received Jan 20, 2019 / Accepted Jun 18, 2019 / Published Jul 05, 2019 
large organizations have focused on recruiting, developing, and maintaining talented employees with little emphasis, which is documented by the Malaysian productivity company in 2009 (Dewi et al., 2015).

Retention of employees and talent management are the practices of successful companies and are essential elements for maintaining leadership and development in the market. Employees' commitment leads to higher customer satisfaction and loyalty, especially in the service sector (Mehta et al., 2014). Talent Management can be seen as a specific way of attracting and retaining key knowledge and abilities of the future (Green, 2000; AimanSmith et al., 2006). Most of the talent management approaches are compatible with rational management of human resources strategy and international human resource management (Stahl et al., 2012). Talent management is the knowledge of using strategic human resources to improve business value. And it allows companies and organizations to achieve their goals. Any activity that leads to attract, retain, develop, and reward individuals, as well as strategic workforce planning, is a part of talent management (Cascio, 2006).

Talent management is a major motivation for organizational success. Talent management is integrated implementation of strategies or systems designed to increase productivity in the workplace by the development of improved processes to attract, develop, retain and use of people with the skills and talent needed to meet the current and future business needs (Oehley \& Theron, 2010). A study by Koketso (2011), showed that the employees of government institutions leave a place for better career development prospects provided in somewhere else. It is not surprising that almost $90 \%$ of respondents in the sample showed a mismatch between their knowledge and skills and their position in local governments. In addition, participants were disappointed mainly due to the lack of management support in terms of mentoring and coaching. A report by the Public Service Commission (2010), found that many public service managers are not competent in human resource functions such as compensation, recruitment and selection, performance management, safety, organizational development, and wellness. These acts are very important to effectively manage a talented workforce in the public sectors (Barkhuizen, 2014). In general, talent management in human resource planning includes the process of identifying, selecting, developing, and retaining talented staffs in the organization (Dewi et al., 2015).

\section{Literature Review}

\section{Entrepreneurship}

Creativity and risky business provide fuel for a modern economy motor. Entrepreneurship is at the top of risky business, in search of opportunity and creativity and is often seen as the instrument for their success. Entrepreneurs consider the change as a normal phenomenon and re always in search of change, react to it and use it as an opportunity (Meier \& Sears, 1989).

Organizational entrepreneurship is the culture dedicated to innovation in products and services with new ideas and the courage to achieve optimal benefit. In other words, it is a set of behaviors and strategies supported by organizational culture and structure to improve and use pioneers' creativity and innovation towards sustainable development and excellence of the organization (Moqimi, 2009). Also, (Anthony et al., 2017; Ogunsiji et al., 2017) organizational entrepreneurship targeted the company is the readiness of employees in large companies with the assumption that entrepreneurial behavior and communication are working with bureaucratic organizations in order to overcome various obstacles to develop new products and services (Burns, 2011). From Zahra's (1991), point of view entrepreneurship refers to the process of creating new business in the company to improve organizational profitability, enhance the competitive position of a company, and strategically renew the existing business (ZAHRA, 1991).

Organizational entrepreneurship's necessity is regarded as the key factor for survival in "today compression competition" due to incompatibility and slow reaction of medium and large organizations in comparison to increase of rapid complex and unreliable changes in the environment and the introduction of fast actions and innovation (Yazdanbakhsh, 2012).

According to the views of some scholars, organizational entrepreneurship is based on the ability of organizations to get through by the utilization of new and the current knowledge. The role of entrepreneurship in a company is to develop competitive advantage and keep it steady (Saeedeh Shirkhani \& Nazari, 2014).

\section{Organizational Entrepreneurship}

In order to be successful in global competition, an organization must develop products and new businesses in the shortest time and with higher quality comparing to the current competition. There is no doubt that the process of 
product and new business development must be very effective, and this process should be supported by an appropriate culture throughout the organization. In an organization that has an innovative culture, all employees at all levels welcome new comments and ideas and are very dynamic in creating new approaches and new ways of doing things. In such an organization there is a willingness to take risks and remove the obstacles (Farhangi \& Safarzadeh, 2007). Entrepreneurs are value-creating; they are innovators who are enjoying the creative destruction techniques in order to maximize economic benefits (Dees, 2004).

Today, entrepreneurs and entrepreneurial companies walk along with changes and try to discover and exploit the opportunities created by these changes. Discovering opportunities include the knowledge that entrepreneurs use to determine decisions and often originates from their previous knowledge and experiences (Safarzad \& Farahnaki, 2016).

Organizational entrepreneurship refers to different types of entrepreneurial behavior in large organizations, with the aim of achieving competitive advantages at all levels by encouraging innovation, including large incorporates, divisions, business units, business performance and project team (Burns, 2011).

Organizational entrepreneurship includes the use of the fruits of the innovation process to help companies to create new sources of competitive advantages and renew their value proposition (Dess et al., 2006).

\section{Talent Management}

In early 1997, Mackenzie et al. introduced the phrase war for talent to describe the challenges faced by employers to find highly skilled candidates (Michaels et al., 2001).

The intellectual roots of talent management can be traced back to human resource planning movement of the 1980s and 1990s, focusing on the communication needs of human resources rather than business needs and succession planning. Following the focus on recruitment, career development of talent domains and with the advent of HR as a strategic business partner, it was increasingly argued that the organization should see talent as a strategic resource (Silzer \& Dowell, 2010).

Talent management ensures the use of an integrated set of activities to attract, retain, motivate and develop talented individuals needed for the organizations' present and future time (Armstrong, 2007).

A general definition of talent management includes precision instruments of unifying strategies or processes to improve the output of a workplace with the establishment of improved systems and processes to attract, develop, retain and use skills and abilities of talented workforce consistent with business needs of the present and future. Talent management usually involves the identification, development, evaluation, deployment, and use of potential employees with high performance (Collings \& Scullion, 2006).

What is talent? And how does talent management help organizations?

Talent is considered as an individual's relative level of development in an activity. If different people are placed on an equal footing to gain skills in an activity, we will realize that various individuals show some differences in terms of acquisition of those skills. Some people show better learning and greater efficiency in a specific field and their developments would be faster in that field, while other people may show greater self-efficacy, skill, and improvement in other fields (Ekayani et al., 2018; Tripathy, 2018).

In fact, such a difference relates to their differences in talent. Everyone has talent, but only those who decide to invest in their development are talented. And this manifests at the workplace that people can demonstrate their competence to create value (Schoemaker, 2003). Phillips et al., (2009), provides a good model, focusing along with shared values, which must be placed at the core of an organization. In this model, all actions associated with talent management can be derived. In this context, there are five key elements: attracting, selecting, engaging, developing, and retaining employees. Main values and competencies are at the core of an organization. These elements are connected through an ongoing process that involves strategy, implementation, and evaluation (Phillips \& Roper, 2009). 


\section{Talent Management Process}

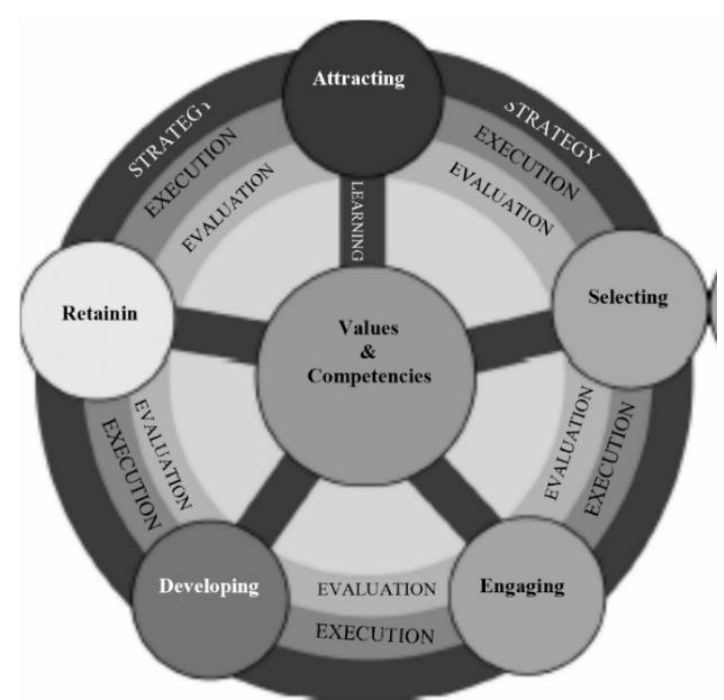

Figure 1.Values and competencies model

Talent management process is one of the important processes in which adjusting, changing, and developing are conducted in order to ensure that the process remains in line with organizational strategies and goals. The emphasis here is on the concept of talent management as a continuous process and not as an intervention in a limited time (Kawiana et al., 2018).

This process shows in figure 2 that a conceptual framework of the talent management process is depicted in various stages. The format of this diagram shows the process requires re-evaluation and re-development constantly. The framework used to discuss each stage of the talent management process and factors must be considered at every stage. To detail this process, a list of a number of techniques that have been proposed (and in some cases R) in the management literature as a strategy to recruit, hire, develop and retain talented employees follows (Oehley, 2007).

\begin{tabular}{|c|c|c|c|c|}
\hline \multicolumn{5}{|l|}{ Project Phases } \\
\hline \multicolumn{2}{|l|}{$\begin{array}{l}\text { Evaluation and } \\
\text { Renewal } \\
\text { Measure } \\
\text {, research and } \\
\text { develop }\end{array}$} & $\begin{array}{l}\text { INTERNAL } \\
\text { - Exit interviews } \\
\text { - Workplace Surveys } \\
\text { - Balanced scorecard }\end{array}$ & \multicolumn{2}{|c|}{$\begin{array}{l}\text { EXTERNAL } \\
\text { - Benchmarking against industry leaders } \\
\text { - Best company to work for ranking }\end{array}$} \\
\hline $\begin{array}{l}\text { Implementation and } \\
\text { integration } \\
\text { Integrative } \\
\text { activities and HR } \\
\text { processes }\end{array}$ & $\begin{array}{l}\text { Attr } \\
\text { - So } \\
\text { - E } \\
\text { Prop } \\
\text { - Re } \\
\text { - Co } \\
\text { - Ps }\end{array}$ & $\begin{array}{l}\text { act and Recruit } \\
\text { urcing of applicants } \\
\text { mployee Value } \\
\text { osition } \\
\text { alistic job previews } \\
\text { mpelling offer } \\
\text { ychological contract }\end{array}$ & $\begin{array}{l}\text { Develop } \\
\text { - Training and } \\
\text { development } \\
\text { - Performance } \\
\text { Management } \\
\text { - Succession planning } \\
\text { - Talent reviews } \\
\text { - Talent pool }\end{array}$ & $\begin{array}{l}\text { Retain } \\
\text { - Challenging work } \\
\text { The impact of line } \\
\text { management } \\
\text { - Remunerate and } \\
\text { reward } \\
\text { - Work life balance }\end{array}$ \\
\hline
\end{tabular}




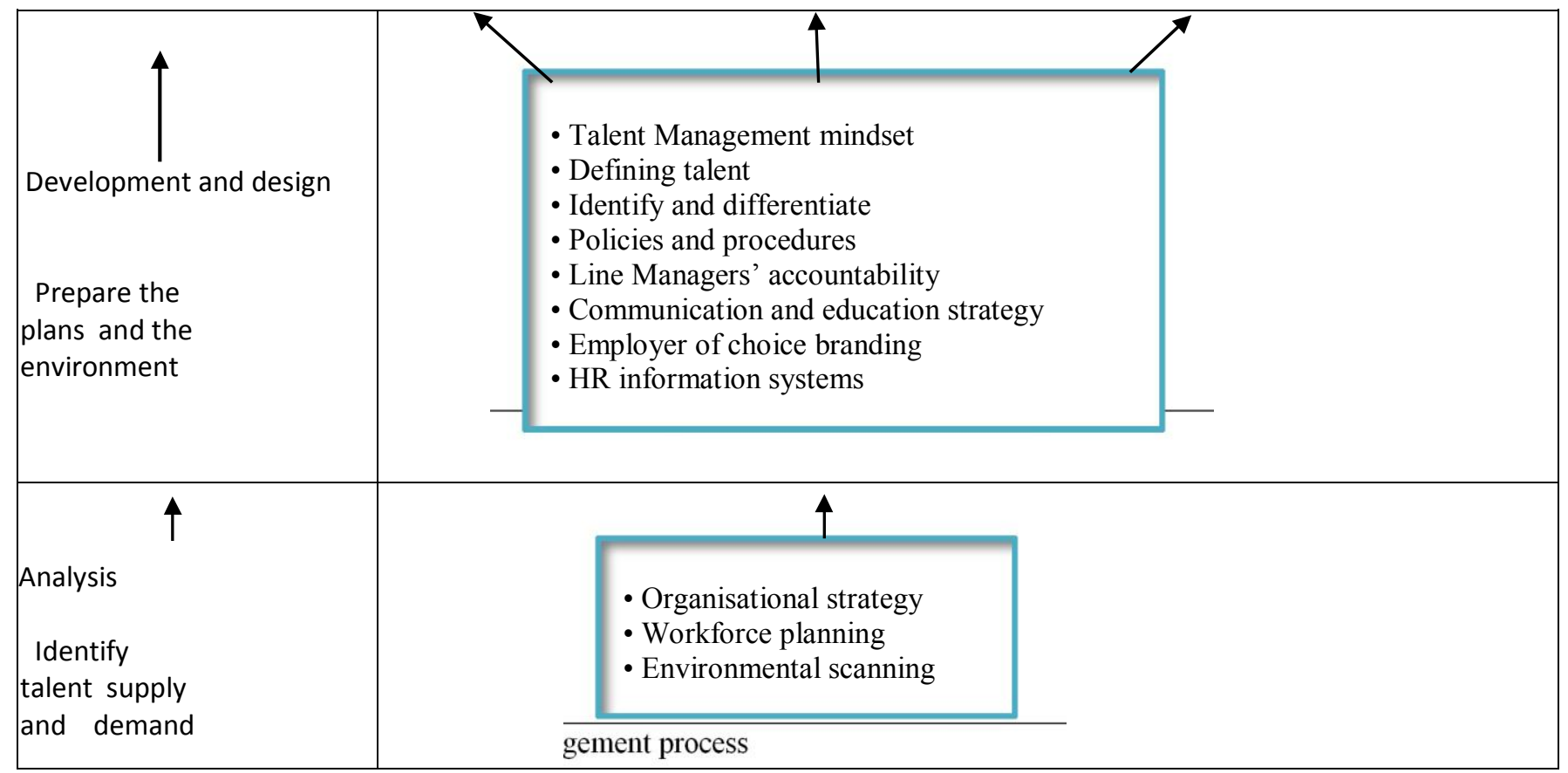

Figure 2. Conceptual framework of the Talent Management process

\section{Research Background}

Haj Nabi et al., has studied "Relationship between talent management and performance of nursing staff in Karaj". Between employee performance and talent management in government hospitals, there is a significant relationship. With the joint efforts of managers and nursing staff and giving more responsibility to the Department of Human Resources, will be the most positive consequences of the behavior and performance of employees created (Hajy Nby et al., 2013).

Shirkhani et al. have studied" An Examination of The Effect of Talent Management on Organizational Entrepreneurship, A Case Study: Oil Products Company of Province of Ilam in Iran. Results obtained from secondary hypotheses indicated that there is a positive significant relationship between talent attraction, talent retention, and talent development, and these components are effective on entrepreneurship. In addition, results of prioritization of questionnaire dimensions revealed that talent attraction has the highest effect and talent retention has the lowest effect upon organizational entrepreneurship. In this regard, it is suggested to consider some measures for attracting, aligning, retention, and developing talents in realizing organizational entrepreneurship (Shirkhani et al., 2014). 
The Proposed Model for the Research

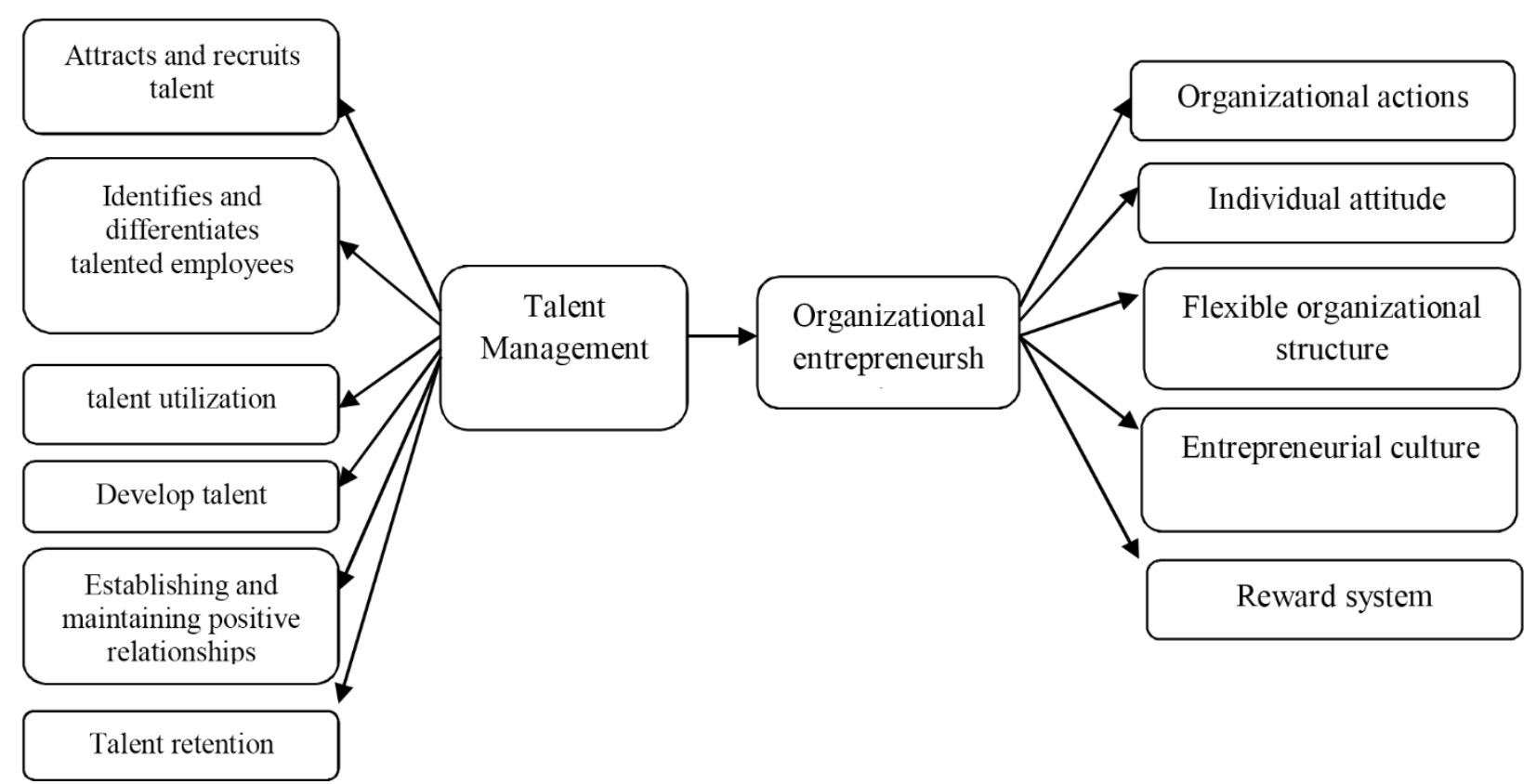

Figure 3. Conceptual model of the research

\section{Methodology}

The present study is of applied type based on its nature and objectives, and the descriptive and correlational methods of data collection are used to test hypotheses.

The population of the study: it includes experts and managers who have at least 7 years' experience and are members of Golestan province Gas Companies. According to Morgan table, for a population of 51 people, 38 is enough. To be confident, 56 questionnaires were distributed among the experts. After collecting the questionnaires and removing the defaced ones, 51 questionnaires were analyzed.

\section{Instruments}

To assess the Talent Management variable, Anne-Marguerite Oehley's talent management questionnaire was used. This questionnaire consists of 6 components and includes a total 36 questions. Also, to measure Organizational Entrepreneurship variable, Margaret Hill's organizational entrepreneurship questionnaire was used. This questionnaire consists of 5 components and includes a total 38 questions.

SPSS software was run to analyze descriptive data, and in order to analyze inferential data SMART PLS software was used.

\section{Reliability}

To ensure the fit of the measuring model of the study, coefficients of factor loadings, Cronbach's alpha coefficient, composite reliability coefficient, and convergent and divergent validity were used.

\section{Factor Loadings Coefficients}

The criterion for the appropriateness of factor loadings coefficients is .4 (Holland, 1999). As it can be seen, the load factors of the questions illustrated in the following figure are higher than .4 which indicates the appropriateness of this criterion to examine the reliability (Davari \& Rezazadeh, 2014). 


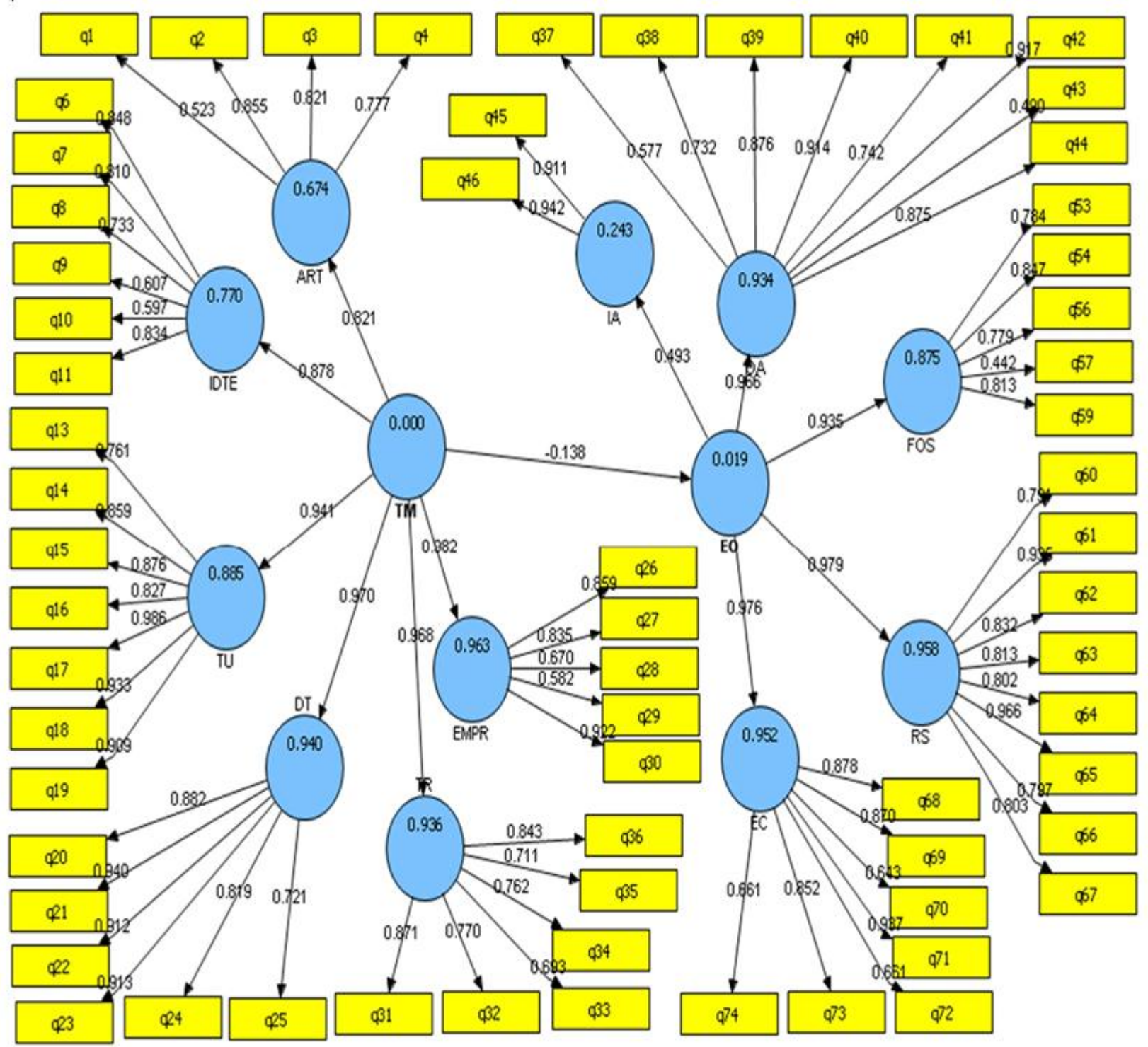

Figure 4. Factor loadings coefficients of the research model

Cronbach's Alpha Coefficient, Composite Reliability Coefficient, and Convergent

\section{Validity}

Internal reliability indicates the correlation between a construct and its corresponding indices. Cronbach's alpha value above .7 indicates acceptable reliability. According to Table 1, in the present paper, Cronbach's alpha values for all variables are higher than 7, indicating good reliability of the questionnaire. Since Cronbach's alpha standard is a traditional criterion to determine the reliability of a construct, PLS method, which is a more modern standard than the Cronbach's alpha composite reliability (CR), is used. If the amount of composite reliability for any construct be above .7, it indicates an appropriate internal consistency for the measurement model (Davari \& Rezazadeh, 2014). The composite reliability coefficient of all variables is above 0.7 .

\section{Convergent Validity}

This is the second criterion used to fit the measuring models in the PLS method. AVE criterion indicates the average variance shared between each construct with its index; and the greater the correlation, the better the fit of the model 
(Barclay et al., 1995). Fornell \& Lurker (1981), considered the extracted average variance over .5 appropriate (Davari \& Reza Zadeh, 1393). According to Table 2, the average variance of all variables, except for the latent variables of the second order, is above this level which indicates the good convergent validity of the research model.

Table 1

Cronbach's Alpha Coefficient, Composite Reliability Coefficient, and Convergent Validity The extracted average Composite Reliability Cronbach's alpha Latent variables Symbols in variance coefficient coefficients the model AVE>0.5 Alpha>0.7 Alpha $>0.7$

\begin{tabular}{|c|c|c|c|c|}
\hline 0.570276 & 0.837389 & 0.732947 & Attracts and recruits talent & ART \\
\hline 0.753034 & 0.947805 & 0.933239 & Develop talent & DT \\
\hline 0.631159 & 0.921398 & 0.897192 & Entrepreneurial culture & $\mathrm{EC}$ \\
\hline 0.614417 & 0.885823 & 0.833683 & $\begin{array}{l}\text { Establishing and maintaining } \\
\text { positive relationships }\end{array}$ & EMPR \\
\hline 0.450546 & 0.960046 & 0.952634 & $\begin{array}{l}\text { Entrepreneurship } \\
\text { organizational }\end{array}$ & $\mathrm{EO}$ \\
\hline 0.559504 & 0.859235 & 0.797708 & $\begin{array}{l}\text { Flexible organizational } \\
\text { structure, flexibility }\end{array}$ & FOS \\
\hline 0.858404 & 0.923789 & 0.836665 & Individual approaches & IA \\
\hline 0.555688 & 0.880397 & 0.836054 & $\begin{array}{l}\text { Identifies and differentiates } \\
\text { talented employees }\end{array}$ & IDTE \\
\hline 0.608916 & 0.923019 & 0.90095 & Organizational actions & $\mathrm{OA}$ \\
\hline 0.713751 & 0.951999 & 0.941641 & Rewarding system & $\mathrm{RS}$ \\
\hline 0.539215 & 0.974116 & 0.969596 & Talent managment & $\mathrm{TM}$ \\
\hline 0.604663 & 0.901126 & 0.868111 & Talent retention & TR \\
\hline 0.776659 & 0.960313 & 0.950951 & talent utilization & TU \\
\hline
\end{tabular}

In the case of latent variables of second and higher orders, CR and AVE values should be calculated by manually because the software calculates them incorrectly and reports them in the output of Table 1 derived from software (Davari \& Reza Zadeh, 2014).

\section{Manual Calculation of $C R$}

For a latent variable of the second order, the manual calculation is done through measurement error variance of its dimensions. So that, for variables of talent management and organizational entrepreneurship is as follows.

The variance of error (dimention) $=1$ - (loading factor coefficient of intra-dimension and its related latent variable of second order) 2

The variance of error $($ ART $)=1-(0.821)^{2}=0.3259$

The variance of error $($ IDTE $)=1-(0.878)^{2}=0.2291$

The variance of error $(\mathrm{YU})=1-(0.941)^{2}=0.1145$

The variance of error $(\mathrm{DT})=1-(0.970)^{2}=0.0591$

The variance of error $(\mathrm{TR})=1-(0.936)^{2}=0.1239$

The variance of error $($ EMPR $)=1-(0.982)^{2}=0.0356$

$$
\begin{aligned}
& \text { ( ) } \\
& =\frac{(.821+.878+.941+.970+.936+.982)}{(.821+.878+.941+.970+.936+.982)+(.3259+.2291+.1145+.0591+.1239+.0356)} \\
& =0.97175
\end{aligned}
$$

The variance of error $(\mathrm{IA})=1-(0.493)^{2}=0.7569$

The variance of error $(\mathrm{OA})=1-(0.966)^{2}=0.0668$

The variance of error $(\mathrm{FOS})=1-(0.935)^{2}=0.1257$

The variance of error $(\mathrm{RS})=1-(0.979)^{2}=0.0415$ 
The variance of error $(\mathrm{EC})=1-(0.976)^{2}=0.0474$

$$
\begin{aligned}
& =\frac{(.493+.966+.935+.979+.976)}{(.493+.966+.935+.979+.976)+(.7569+.0668+.1257+.0415+.0474)} \\
& =0.9479 \\
& ]
\end{aligned}
$$

\section{Manual Calculation of AVE}

For a variable of second order, it is equal to the mean of square values of the factor loadings. So, for both variables, talent management and organizational entrepreneurship, is as follows.

$$
\begin{aligned}
(0.821)^{2} & =.6740 \\
(0.878)^{2} & =.7708 \\
(0.941)^{2} & =.8854 \\
(0.970)^{2} & =.9409 \\
(0.936)^{2} & =.8760 \\
(0.982)^{2} & =.9643 \\
& \text { AVE }(\mathrm{TM})=\frac{(.6740+.7708+.8854+.9409+.8760+.9643)}{6}=0.85159
\end{aligned}
$$

$$
(0.493)^{2}=.2430
$$

$$
\begin{aligned}
& (0.966)^{2}=.9331 \\
& (0.935)^{2}=.8742 \\
& (0.979)^{2}=.9584 \\
& (0.976)^{2}=.9525
\end{aligned}
$$

$$
\operatorname{AVE}(E O)=\frac{(.2430+.9331+.8742+.9584+.9525)}{5}=0.79224
$$

\section{Overall Fit Model}

GOF criterion, a model that includes both parts of structural and measurements, and by approving its fit, assessment of the fit of a model is complete. Vitzls et al., (2009), introduced three values of $.01, .25, .36$ as low, medium, and strong for GOF, respectively (Davari \& Rezazadeh, 2014). In this study, the total amount of .628 for the overall fit of the model indicates a strong overall fit of the model.

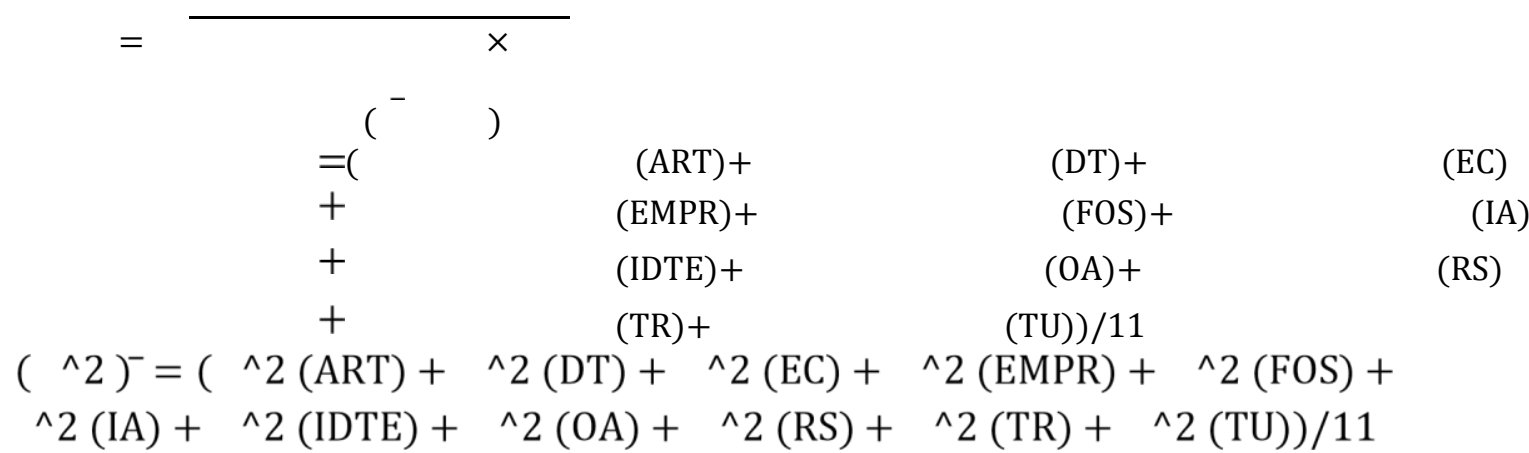

Table 2

Communality, R Square

\begin{tabular}{lccc}
\hline Communality & & \multicolumn{2}{c}{ R Square } \\
\hline ART & 0.570276 & ART & 0.674159 \\
DT & 0.753034 & DT & 0.940219 \\
EC & 0.631159 & EC & 0.952097 \\
EMPR & 0.614417 & EMPR & 0.963344
\end{tabular}




\begin{tabular}{llcl} 
EO & 0.450547 & EO & 0.019134 \\
FOS & 0.559503 & FOS & 0.875122 \\
\hline IA & 0.858404 & IA & 0.243073 \\
IDTE & 0.555688 & IDTE & 0.770337 \\
OA & 0.608916 & OA & 0.933844 \\
RS & 0.713751 & RS & 0.957875 \\
TM & 0.539215 & TM & \\
TR & 0.604663 & TR & 0.936305 \\
TU & 0.776659 & TU & 0.884643 \\
\hline
\end{tabular}

$$
\begin{aligned}
& =0.633556 \\
& =.703858 \\
& =0.66778
\end{aligned}
$$

\section{Discussion and Conclusion}

Respondents were 51 staffs who were randomly selected. Demographic information of the participants is presented in the following Tables.

\begin{tabular}{|c|c|c|c|c|c|c|}
\hline & & & \multicolumn{3}{|c|}{ Education } & \multirow[t]{2}{*}{ Total } \\
\hline & & & $\begin{array}{c}\text { Associate } \\
\text { degree }\end{array}$ & B.A & M.A. & \\
\hline \multirow[t]{3}{*}{ Age } & $<30$ & 0 & 0 & 0 & & \\
\hline & & $30-40$ & 0 & 9 & 15 & 24 \\
\hline & & $>50$ & 2 & 0 & 1 & 3 \\
\hline \multirow{2}{*}{\multicolumn{2}{|c|}{ Total }} & & 2 & 26 & 23 & 51 \\
\hline & & $41-50$ & 0 & 17 & 7 & 24 \\
\hline
\end{tabular}

Table 3

Descriptive information of the educational level and age of the sample

\section{Analysis of the Research Hypotheses}

According to the data analysis algorithm in PLS method indicated in figure 4, if the significant coefficient of the path model (z significant factor) is greater than 1.96, it represents significant assumptions at a confidence level of $95 \%$ (Davari \& Rezazadeh, 2014). 


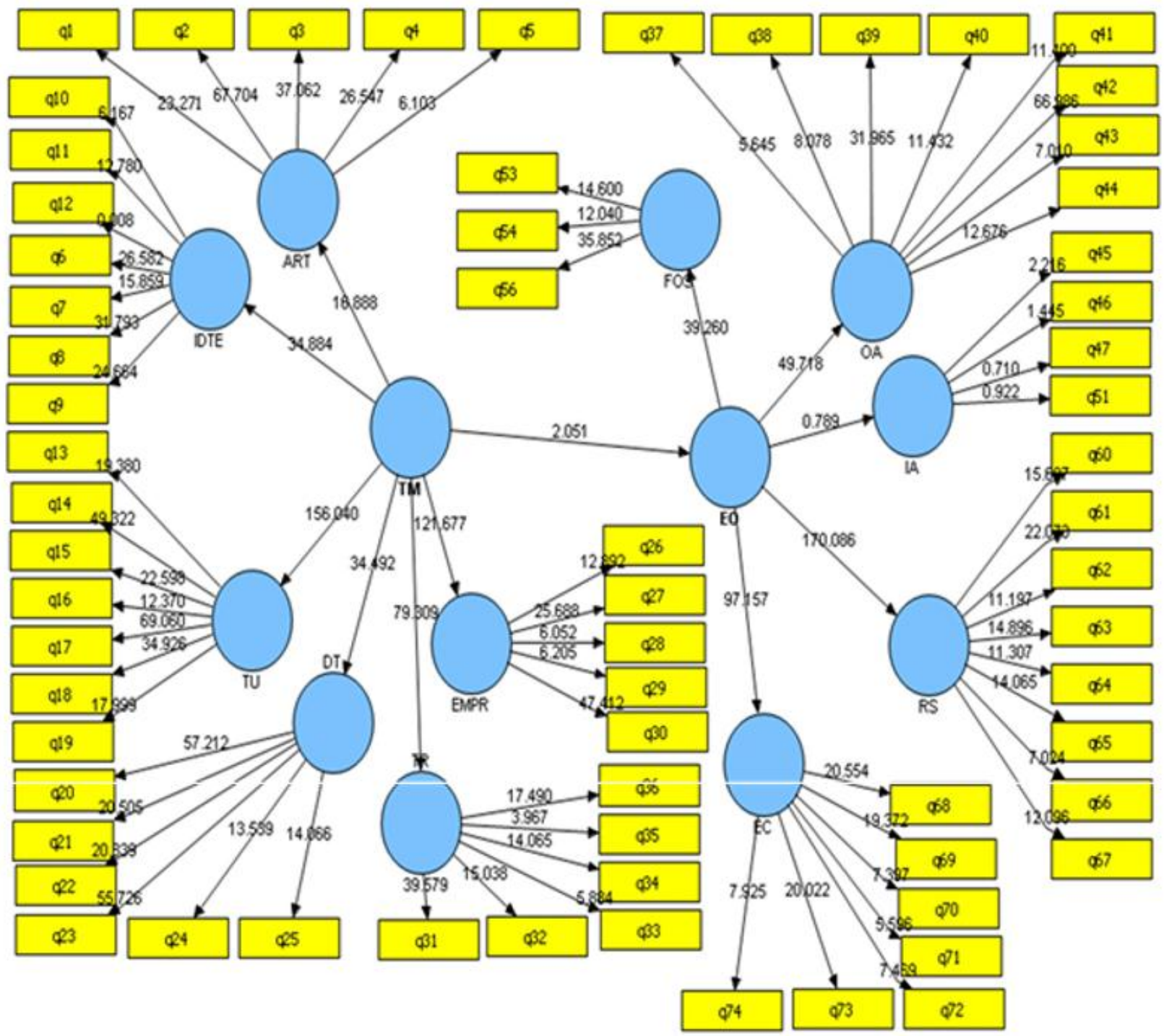

Figure 5. Data analysis algorithm in the PLS method

The changing world, advances in technology, cultural diversity, changes in the customers' interests and tastes, the need for new products and services according to customers' wishes are among the factors that organizations should be aware of. Organizations need creative, flexible and responsive staffs to create new ideas, meet the customers' every day and win their satisfaction. Undoubtedly, talent management, which is one of the most important issues in the field of human resources, can help large and small organizations that want to achieve superiority over competitors to design a talent management system in order to gain competitive advantage. The results of this study (Figure 5) showed that there was a significant correlation between talent management and entrepreneurship. And this is consistent with the results obtained by other researchers like Shafiee Nikabadi \& Tavangarmarvasti (2015) and Rashidi (2013).

But some organizations design their system for utilization of potential resources in various stages of work; this rotary system prevents having high expectations from people in the early stages of work and pays no attention to individuals who show slow progress. However, each organization must coordinate its own talent management system with the specific conditions of the industry or business to take maximum advantage of it. Meanwhile, in taking advantage of the talent management system it should be noted that its implementation should not cause separation between people in the organization which is in conflict with the talent management goals. 


\section{References}

Aiman-Smith, L., Bergey, P., Cantwell, A., \& Doran, M. (2011). The coming knowledge and capability shortage. IEEE Engineering Management Review, 3(39), 3-14.

Al-Fadhli, H. (2014). Talent Management within Small Businesses in Kuwait. In The Clute Institute International Academic Conference (pp. 179-180).

Anthony, K. A., Oshoke, S., \& Slyvester, O. (2017). Assessment of entrepreneurial education and diversity management: a gateway to sustainable development in Nigeria. International Research Journal of Management, IT and Social Sciences, 4(1), 53-60.

Armstrong, M. (2006). A handbook of human resource management practice. Kogan Page Publishers.

Barclay, D., Higgins, C., \& Thompson, R. (1995). The partial least squares (PLS) approach to casual modeling: personal computer adoption ans use as an Illustration.

Barkhuizen, N. (2014). How relevant is talent management in South African local government institutions?. Mediterranean Journal of Social Sciences, 5(20), 2223.

Burns, P. (2011). Entrepreneurship and Small Business: Start-up Growth.

Cascio, W. F. (2006). Managing Human Resources: productivity, quality of work life, profits 7th Edition Tata McGraw-Hill. Abnormal and Social Psychology, 62, 401-407.

Davari, A., Yassaei, S., Momeni Sarvestani, M., \& Rahnama, A. (2014). Association between Self-esteem and Educational Status of Medical Students of Shahid Sadoughi University of Medical Sciences in Yazd. Yazd Journal of Dental Research-The Journal of Faculty of Dentistry Shahid Sadoughi University of Medical Sciences (quarterly), 3(2), 262-271.

Dees, J. G., Emerson, J., \& Economy, P. (2004). Strategic tools for social entrepreneurs: Enhancing the performance of your enterprising nonprofit (Vol. 207). John Wiley \& Sons.

Dess, G. G., Lumpkin, G. T., \& Eisner, A. B. (2006). Strategic Management: Creating.

Du Plessis, L. (2013). The relationship between perceived talent management practices, perceived organizational support (POS), perceived supervisor support (PSS) and intention to quit amongst Generation Y employees in the recruitment sector (Doctoral dissertation, University of Pretoria).

Ekayani, I. A. P. H., Susrusa, K. B., Suardi, I. D. P. O., \& Putra, I. G. S. A. (2018). Entrepreneur community prospect of snack made from local food by balinese women. International Journal of Life Sciences, 2(3), 151163. https://doi.org/10.29332/ijls.v2n3.237

Farhangi, A., \& Safarzadeh, H. (2007). Entrepreneurship (concepts, theories, models and applications). Work and social security organization. Tehran.

Fornell, C., \& Larcker, D. F. (1981). Evaluating structural equation models with unobservable variables and measurement orror. Journal marketing research, 18(1), 39-50. https://doi.org/10.1177\%2F002224378101800104

Green, M. E. (2000). Beware and prepare: The government workforce of the future. Public Personnel Management, 29(4), 435-444. https://doi.org/10.1177\%2F009102600002900402

Hajy $\neg$ Nby, Cameron, President, P. and oven, Nrgs $\neg$ Alsadat (2013). Talent management relationship with the nursing staff in hospitals in the city of Karaj, Health Information Management, 10 (7): 469-472.

Holland, C. R., \& Light, B. (1999). A critical success factors model for ERP implementation. IEEE software, 16(3), 30-36.

Kawiana, I. G. P., Dewi, L. K. C., Martini, L. K. B., \& Suardana, I. B. R. (2018). The influence of organizational culture, employee satisfaction, personality, and organizational commitment towards employee performance. International Research Journal of Management, IT and Social Sciences, 5(3), 35-45.

Koketso, L. (2015). STEM education in Botswana: understanding the gender disparity in enrolment and graduation in post-secondary education (Doctoral dissertation, Concordia University).

Mehta, M., Kurbetti, A., \& Dhankhar, R. (2014). Review paper-study on employee retention and commitment. International journal of advance research in computer science and management studies, 2(2), 154164.

Michaels, E., Handfield-Jones, H., \& Axelrod, B. (2001). The war for talent. Harvard Business Press.

Moqimi, S. M. (2009). The effective factors on organizational entrepreneurship in social and cultural services of state sector in Iran. Journal of Management Culture, 2(7), 27-78.

Oehley, A. M. (2007). The development and evaluation of a partial talent management competency model (Doctoral dissertation, Stellenbosch: University of Stellenbosch).

Oehley, A. M., \& Theron, C. C. (2010). The development and evaluation of a partial talent management structural model. Management Dynamics: Journal of the Southern African Institute for Management Scientists, 19(3), 2-28. 
Ogunsiji, A. S., \& Ladanu, W. K. (2017). A theoretical study of performance measures in the strategic and corporate entrepreneurship of firms. International Journal of Life Sciences, 1(1), 49-57. https://doi.org/10.21744/ijls.v1i1.23

Phillips, D. H. (2009). Permeable reactive barriers: A sustainable technology for cleaning contaminated groundwater in developing countries. Desalination, 248(1-3), 352-359. https://doi.org/10.1016/j.desal.2008.05.075

Phillips, D. R., \& Roper, K. O. (2009). A framework for talent management in real estate. Journal of Corporate Real Estate, 11(1), 7-16. https://doi.org/10.1108/14630010910940525

Rashidi, F., Jalili, A., Kafaki, S. B., Sagheb-Talebi, K., \& Hodgson, J. (2012). Anatomical responses of leaves of Black Locust (Robinia pseudoacacia L.) to urban pollutant gases and climatic factors. Trees, 26(2), 363-375. https://doi.org/10.1007/s00468-011-0598-y

Rashidi, M. M., Abelman, S., \& Mehr, N. F. (2013). Entropy generation in steady MHD flow due to a rotating porous disk in a nanofluid. International Journal of Heat and Mass Transfer, 62, 515-525. https://doi.org/10.1016/j.ijheatmasstransfer.2013.03.004

Safarzad, R., Farahnaki, E., \& Farahbakhsh, M. (2016). Corporate Social Responsibility, Theories and Models. Theories and Models (September 3, 2016).

Schoemaker, M. J. R. (2003). De metamorfose van werkgemeenschappen. [Nijmegen]: Katholieke Universiteit Nijmegen.

Scullion, H. U. G. H., \& Collings, D. (2006). International talent management. Global staffing, 87-116.

Sears, J. D., Greven, K. M., Hoen, H. M., \& Randall, M. E. (1994). Prognostic factors and treatment outcome for patients with locally recurrent endometrial cancer. Cancer, 74(4), 1303-1308. https://doi.org/10.1002/10970142(19940815)74:4\%3C1303::AID-CNCR2820740420\%3E3.0.CO;2-G

Shafie nikAbadi, M., \& Dehghan, M. (2014). Identify and assess the relative importance of knowledge management strategies by using ANN (Case study Knowledge base Software Companies). Journal of Industry and University, 7(21), 73-86.

Shirkhani, R., Jazayeri-Rad, H., \& Hashemi, S. J. (2014). Modeling of a solid oxide fuel cell power plant using an ensemble of neural networks based on a combination of the adaptive particle swarm optimization and LevenbergMarquardt algorithms. Journal of Natural Gas Science and Engineering, 21, 1171-1183. https://doi.org/10.1016/j.jngse.2014.07.004

Shirkhani, S., \& Nazari, R. (2014). An Examination of the Effect of Talent Management on Organizational Entrepreneurship: A Case Study Oil Products Company of Province of Ilam in Iran. Kuwait Chapter of Arabian Journal of Business and Management Review, 33(2572), 1-8.

Silzer, R., \& Dowell, B. E. (2010). Strategic talent management matters. Strategy-driven talent management: A leadership imperative, 3-72.

Stahl, G., Björkman, I., Farndale, E., Morris, S. S., Paauwe, J., Stiles, P., ... \& Wright, P. (2012). Six principles of effective global talent management. Sloan Management Review, 53(2), 25-42.

Tajuddin, D., Ali, R., \& Kamaruddin, B. H. (2015). Developing talent management crisis model for quality life of bank employees in Malaysia. Procedia-Social and Behavioral Sciences, 201, 80-84. https://doi.org/10.1016/j.sbspro.2015.08.133

Tripathy, M. (2018). Building quality teamwork to achieve excellence in business organizations. International Research Journal of Management, IT and Social Sciences, 5(3), 1-7.

Vitz, J., Erdmenger, T., Haensch, C., \& Schubert, U. S. (2009). Extended dissolution studies of cellulose in imidazolium based ionic liquids. Green chemistry, 11(3), 417-424.

Vural, Y., Vardarlier, P., \& Aykir, A. (2012). The effects of using talent management with performance evaluation system over employee commitment. Procedia-Social and Behavioral Sciences, 58, 340-349. https://doi.org/10.1016/j.sbspro.2012.09.1009

Yazdanbakhsh, M. (2012). organizational entrepreneurship, public management, 2012, association of Sanat Pakhsh Companies.

Zahra, S. A. (1991). Predictors and financial outcomes of corporate entrepreneurship: An exploratory study. Journal of business venturing, 6(4), 259-285. https://doi.org/10.1016/0883-9026(91)90019-A 